\title{
Perceptions of student affairs and services practitioners in Ontario's post-secondary institutions: An examination of colleges and universities
}

Tricia A. Seifert

Jeff Burrow

Ontario Institute for Studies in Education, University of Toronto

\begin{abstract}
Student affairs and services divisions and the partnerships and collaborations in which they engage with faculty, students, and the community form the structural centre of institutions' approaches to student support. Although past research has identified areas typically associated with the student affairs and services portfolio and factors that influence the organizational structure, little is known about how staff perceive their institutions' organizational structures relative to supporting student success. The purpose of this study was to understand student affairs and services staff members' perceptions of the role organizational structure plays in their day-to-day work supporting student success in colleges and universities in Ontario. Although staff commented on their institutions' formal organizational structures (referring to titles, reporting lines, and breadth of portfolio), their comments focused more specifically on how they saw the nature of their work and changes they have experienced in supporting student success as student bodies become more diverse.
\end{abstract}

\section{Résumé}

Les divisions des services aux étudiants et des affaires étudiantes, de même que les partenariats et collaborations qu'elles forment avec la faculté, les étudiants et la communauté façonnent le centre structurel des approches des établissements 
envers le soutien des étudiants. Bien qu'une précédente recherche ait identifié des domaines typiquement associés au dossier des affaires étudiantes et des services aux étudiants, ainsi qu'à des facteurs qui influencent la structure organisationnelle, on n'en sait pas beaucoup quant à la perception du personnel de ces établissements envers les structures organisationnelles de leur établissement et leur façon d'appuyer la réussite des étudiants. L'objet de cette étude était de comprendre les perceptions du personnel des affaires étudiantes et des services aux étudiants envers le rôle de la structure organisationnelle dans leur travail quotidien de soutien à la réussite des étudiant(e)s des collèges et universités de l'Ontario. Bien que le personnel ait formulé des remarques sur les structures organisationnelles de leur établissement (les titres, les liens hiérarchiques et l'ampleur des services offerts), leurs commentaires ont ciblé plus précisément leur perception quant à la nature de leur travail et les changements qu'ils ont subi en appuyant la réussite des étudiants en raison d'une population étudiante de plus en plus diversifiée.

As post-secondary education in Canada has moved from being the sole purview of society's privileged class to being accessible to a wider cross-section of the population (Composite Learning Index, 2010; Drewes, 2008), supporting students through post-secondary completion has become essential for realizing students' and the public's investment. Accordingly, a host of programs and services have been developed in the last 60 years to support the increasingly diverse student body in attaining educational goals (Andres \& Finlay, 2004; Dennison \& Gallagher, 1986; Hardy Cox \& Strange, 2010). Student affairs and services (SAS) divisions and the partnerships and collaborations in which they engage with faculty, students, and the community form the structural centre of institutions' approaches to student support. Unlike academic faculties that can be fairly static in their organizational structure, SAS divisions experience considerable organizational change, with departments joining and departing the division (Kuk, 2009; Manning, Kinzie, \& Schuh, 2006; Seifert, Arnold, Burrow, \& Brown, 2011). Not surprisingly, much of the literature has focused on discussing the areas that tend to function within the SAS portfolio (American Council on Education, 1937, 1949; Crookston, 1994; Dungy, 2003; Hardy Cox \& Strange, 2010; Kuk, 2009; Mueller, 1961). Yet, little research has examined the perspectives of SAS staff to see how they have made meaning of their division's organizational structures, and how staff perceive these organizational structures as helping or hindering their ability to support student success. Student success has been defined in the literature as retention, graduation, and educational attainment (Kuh et al., 2005) and more specifically as "academic achievement, engagement in educationally purposeful activities; satisfaction; acquisition of desired knowledge, skills, and competencies; persistence; educational attainment; and postcollege performance" (Manning, Kinzie, \& Schuh, 2006, pp. 22-23). The purpose of this study was to understand SAS staff members' perceptions of the role organizational structure plays in their day-to-day work supporting student success in colleges and universities in Ontario. 


\section{Literature Review}

As programs and services have been added to the SAS administrative portfolio, a literature has developed that focuses on the distinct organizational area of SAS within postsecondary institutions. The organizational literature of SAS divisions in post-secondary institutions is situated broadly in two streams: (a) description of reporting lines and portfolio responsibilities; and (b) identification of factors that influence SAS divisions' organization and approaches taken by SAS divisions to support student success.

\section{Reporting Lines and Functional Areas}

Extending back to the earliest conception of the field, when the work was referred to as student personnel services, the first stream of literature focused primarily on the reporting lines and functional areas that fell within the SAS portfolio and was based largely within the American context (American Council on Education, 1937, 1949; Crookston, 1994; Dungy, 2003; Kuk, 2009; Mueller, 1961). In Canada, this literature has developed only within the past 20 years (Canadian Association of College and University Student Services [CACUSS], 1989; Hardy Cox \& Strange, 2010; James, 2010; Ouellette, 2010; Sullivan, 2010). Across both national contexts, this stream of literature discussed the opportunities and challenges associated with various reporting lines for the senior student affairs and services officer. The SAS division's senior officer typically reports either to the institution's president or chancellor or to the provost or vice-president, academic; in some cases, a division may have a dual reporting line to both of these senior leaders. Reporting to the president gives the SAS division's senior officer-the person directly representing the student experience-a place at the president's table (Keeling \& Associates, 2011; Sullivan, 2010). However, given the increased expectation for SAS divisions to orient their work toward supporting student learning and success (American College Personnel Association, 1996; Keeling, 2004, 2006; Sullivan; 2010), models in which the SAS division's senior officer reports to the provost clearly situate the division and its priorities, purposes, policies, and practices within the institution's central academic mission (Keeling \& Associates, 2011).

Description of the areas that fall within the SAS portfolio is also a central topic of this stream of literature. Hardy Cox and Strange (2010) provide a useful schema to describe the functional units typically organized within Canadian SAS divisions. As students matriculate, they are exposed to a host of enrolment management functions: admissions, registration services, and financial assistance and scholarship services as well as orientation and first-year programs. Students then receive accommodation from housing services and engage with other students as well as the institution more broadly through their interactions in residence as well as with student leadership, campus clubs and organizations, service learning, and possibly judicial or conflict mediation services. Students are supported through their adjustment to post-secondary study by taking advantage of counselling, health and wellness, and career and employment services; sports and recreation activities; and a host of programs and services available for diverse students (e.g., Aboriginal, international, women, and mature students). With some exceptions, the SAS portfolio from the American context (Dungy, 2003; Kuk, 2009) is quite similar to that which others have identified as characteristic of the Canadian context (Hardy Cox \& Strange, 2010; James, 2010; Ouellette, 2010; Sullivan, 2010). 


\section{Factors That Influence Organizational Structure}

The second literature stream discusses factors that influence the organizational structure of SAS divisions. These factors include funding mechanisms and resource allocation (Ambler, 2000; Seifert et al., 2011; Sullivan, 2010) as well as institutional mission and type (Barr, 2000; Hirt, 2006; Kuk, 2009; Lyons, 1993; Manning, Kinzie, \& Schuh, 2006; Seifert et al., 2011). Some SAS divisions are organized based on a revenue source model in which revenue streams from auxiliary units are reflected in the division's alignment of reporting units (Ambler, 2000). Similarly, Sullivan (2010) stated that SAS organizational structure may be influenced by variations between institutional operating budgets and student fees, and Seifert et al. (2011) found governmental funding envelopes played a role in the development of new SAS units or the expansion of pre-existing units' mandates.

Within the American context, Kuk (2009) draws from her 2007 thesis work and Hirt's (2006) research to summarize common organizational models by various institutional characteristics that contribute to the institutional mission. At institutions with an undergraduate teaching mission, SAS divisions tended to be smaller in scope and flatter in organizational hierarchy. Many staff served either in cross-appointed positions or as generalists, in comparison with staff at master's- and doctorate-granting institutions, who tended to be specialized within a functional area and within a more complex hierarchy. Kuk also noted that SAS divisions at master's-granting institutions tended to have auxiliary unitssuch as housing-sharing a dual reporting line with finance or an administrative area, and the division's senior officer frequently reported to the president and served as a part of the institution's executive team. By comparison, Kuk found, doctorate-granting institutions tended to have auxiliary and fee-funded areas operating largely as self-sustaining entities, and the SAS division's senior officer reported increasingly to the provost while maintaining a voice on the executive team. Community colleges tended to have units that provided academic support services, connecting the SAS division more closely to the academic faculties. Kuk noted that although community colleges have not historically been residential, as they take on greater elements associated with a residential campus character, the mission and breadth of their SAS divisions will likely change as well.

Although there are similarities between the organizational structures of Canadian and American SAS divisions, American institutions exhibit far greater differentiation in organizational type. Although differentiation within the post-secondary system is a topic of much conversation in Ontario (Jones \& Skolnik, 2009; Skolnik, 2005; Weingarten \& Deller, 2010), translating findings from the American context of SAS organizational structure remains problematic. For example, the organizational structure at a private, religiously affiliated liberal arts institution of 2,000 undergraduate students in the United States would be difficult to compare to that of even the smallest publicly funded comprehensive university in Ontario. The American literature comparing the organizational structures of SAS divisions between community colleges and universities is even more difficult to translate, given the stated transfer function of the U.S. community colleges (Brint \& Karabel, 1989; Dougherty, 2001) and the intentionally two-tracked Ontario post-secondary system (Jones, 1997; Skolnik, 2011).

In an effort to provide a localized context for the SAS field in Canada, Seifert et al. (2011) examined the organizational structures of 14 Ontario post-secondary institutions. 
They identified several differences in both reporting lines and portfolios between colleges and universities. At the five colleges in the study, all SAS division senior officers had the title of vice-president and reported directly to the president. The titles and reporting lines were far more diversified among the universities in the sample, with five divisional senior officers having the title of associate vice-president or provost reporting to the provost or vice-president, academic. Although many of the core services identified by Hardy Cox and Strange (2010) were part of the portfolios at both universities and colleges, registration functions were part of the SAS portfolio at all of the colleges and at fewer than half of the universities; housing and residence life staff reported more frequently to a division outside SAS in the colleges than in the universities. Seifert et al. also found that SAS divisions at the colleges were generally more expansive and included alumni affairs, libraries, and/ or external research.

Although the literature's description of organizational structures-reporting lines and breadth of portfolio-is helpful, it does not detail the experiences of SAS staff who work daily within these organizational structures supporting student success. Guided by the following research question, the present study aimed to contribute to the literature by situating the perspectives of staff at the centre of the inquiry. The research question asked: "How do SAS staff at colleges and universities in Ontario perceive organizational structures as influencing staff's ability to support student success?”

\section{Methodology}

Since there is very little past research in the SAS field in Canada and in Ontario specifically, the study is largely descriptive and seeks to better understand the phenomena under investigation. We adopted a reflexive approach seeking both the emic perspective, driven by the question "What sense do I make of what is going on?" (Rossman \& Rallis, 2003, p. 50), and the etic perspective, which seeks to understand the participants' meaning-making processes of how they perceive their institutions' organizational structures with respect to their work supporting student success. Because of the study's intent, qualitative methodology was well suited for this project.

\section{Sample}

Fourteen institutions participated in this study. The institutions were drawn from the two publicly funded post-secondary education sectors within Ontario: colleges and universities. The five participating colleges were re-chartered under the Ontario Colleges of Applied Arts and Technology Act, 2002 with the objectives of offering career-oriented, post-secondary education, assisting individuals to find and keep employment, and meeting the changing local employers' needs in service to the community's economic and social development. The colleges were purposively selected to represent different regions of Ontario and ranged in institutional size from 8,000 to 53,500 full-time and part-time students. All had multiple satellite campuses.

The nine universities in the sample were incorporated under unique acts of the Ontario legislature. Distinct from the expressed vocational nature of the colleges, the objects and purposes of the universities in general are the advancement of learning relative to graduates' intellectual, social, moral, and physical development and the dissemination of 
knowledge, with both purposes serving to better society (see, for example, Brock University Act, 1964). Along with intentional variation in geographic location and size (ranging from 4,100 to 45,000 full-time and part-time students seeking bachelor's degrees or first professional degrees), the universities in this study were purposively selected to range in their age of incorporation, residential mix, and research intensity. For example, one of the universities in the sample was a part of an established multi-campus system; one has a francophone campus; and two have more traditional satellite campuses.

The participants for the study were SAS staff who responded to an email authored by the primary investigator, inviting them to participate in a focus group. Each SAS division's senior officer endorsed the email invitation, which was sent by an on-campus contact person. Each institution's SAS senior officer participated in the study, as did 278 SAS staff from across the 14 institutions. The participating staff represented a wide spectrum of functional areas within the SAS portfolios, including Aboriginal student services, academic learning skills, accessibility/disability services, admissions and recruitment, athletics, counselling (personal, academic, and career), financial aid, health and wellness, international student services, leadership development, orientation, recreation, registrar, and residence life, to name a few.

\section{Data Collection}

We collected interview and focus group data as part of a full-day visit to each site. The visit began with a 60-minute individual interview with the SAS division's senior officer, which focused on understanding the rationale behind the division's organizational structure, recent changes within the division's structure, what precipitated those changes, and how the division related to the broader institution. The site visit continued with three 90-minute focus groups. The first was for those who reported directly to the division's senior officer and comprised mainly the directors and managers of functional areas; the other two focus groups were for staff who reported to those directors and managers of functional areas within the division. The purpose of the audiotaped, semi-structured focus groups was to understand how SAS staff members made sense of their institution's organizational structure and their perceptions of how these organizational structures influenced staff members' ability to support student success. The site visit also included a guided tour of the SAS areas on campus, allowing the research team to see the physical layout of divisional areas. The visit concluded with a follow-up 30-minute interview with the SAS division's senior officer, which provided an opportunity to clarify and comment on topics discussed in the focus groups.

\section{Data Analysis}

After conducting the site visits, members of the research team discussed general impressions about the organizational structure of the institution. These conversations and personal insights were written in team members' memos and summaries. After the site visits were complete, the research team transcribed the interview and focus group audio files.

From the transcripts and team members' memos and institutional summaries, the research team used an open coding procedure to identify, name, and categorize phenomena (Strauss \& Corbin, 1998). Two research team members, working separately, analyzed the 
data using the open coding process for each institution in the sample. The two members then met to compare codes and reconcile inconsistencies. The team members also met with a third person to discuss the analysis and coding. The third research team member was present during the data collection at the specific institution and served as a peer debriefer, checking the credibility and trustworthiness of the analysis (Rossman \& Rallis, 2003).

After reconciling feedback from the peer debriefer, one team member from the pair of coders prepared a detailed institutional site report. The site report described the research team's interpretation of the data based on the open coding process. This narrative report was then provided to the SAS division's senior officer, and a summary was presented to participants in a preliminary report-sharing meeting for their feedback. This form of "member checking" was crucial in that it provided a constructive feedback loop for the participants to verify the trustworthiness of the data analysis (Lincoln \& Guba, 1985, Rossman \& Rallis, 2003). The narrative site reports then became the data from which the research team began the axial coding process of relating categories and properties to each other (Strauss \& Corbin, 1998; Gibson \& Brown, 2009).

\section{Limitations}

The site visits were completed between June and September 2010, with all but three completed during June, July and August. It is possible that the timing of our data collection may have affected the number of SAS staff able to participate. Between summer holidays and contracts of less than 12 months for some staff, the data collected represent only those perspectives of SAS staff available and willing to participate in the study. Although we made every effort to encourage the greatest level of participation at each institution, it is likely that some staff were either not interested or unable to participate in the study. Additionally, the site visits occurred at the main campus of each institution. Although it is possible that staff from the satellite campuses received the invitation to participate, fewer than five participants identified that they worked at one of the satellite campuses. These data reflect almost exclusively the perspectives of SAS staff members on the main campus. We do not attempt to generalize these findings to all SAS staff members at colleges and universities in Ontario or even to those institutions within our sample. We present the results as the product of an iterative process between the research team and the participants' interpretations of the data collected.

\section{Results}

We asked SAS staff to discuss their perceptions of organizational structures within their division and across their institution and to share how they perceived these structures as influencing their ability to support student success. Although staff commented on the formal organizational structures (referring to titles, reporting lines, and breadth of portfolio), their comments focused more specifically on how they saw the nature of their work and changes they have experienced in supporting student success as student bodies become more diverse. They also discussed the role of informal organizational structures such as communication and collaboration within the division and with other stakeholders. As we reviewed the site visit reports from the colleges and universities in the sample separately and then in comparison with one another, it appeared that staff across the two post-secondary sectors in Ontario tended to hold different perspectives. 


\section{Educator Versus Service Provider}

Staff described in great detail how they relied on one another within the division and across the institution to support student success. Yet, part of developing a healthy interdependent reliance required units within the SAS division and across the institution to be familiar with other units' mandates, policies, and practices. One of the ways that this kind of knowledge was generated was through the divisional senior officer making a concerted effort to encourage communication and collaboration between the units. We noticed a difference between the colleges and universities in how they described the cooperation and collaboration between their units. Staff from colleges described units working together to support a student. One example was with accessibility accommodation. This process typically required a registrar's office staff member working with an individual faculty member and a counsellor from the accessibility or disabilities services office. Together, these staff members cooperated in the service of supporting an individual student's success. Often cooperation came as a result of a crisis for the student. According to one college staff member, "People are incredibly responsive. I cannot say enough for the folks I work with because there are times where there are very frightening times with students and we need help."

This type of service-oriented cooperation also took place at the universities in the sample, but there was also more frequently a second orientation, one that was more collaborative in nature. Staff from the universities described collaborating to develop programs outside the classroom learning environments. For example, staff from one university in the sample described the career services and student awards departments collaborating to create an innovative work-study program. Another institution described the collaborative work that the division had undertaken with the faculties to develop a leadership certificate and a civic certificate. In a third example, a university designed a residentially based first-year-experience program, which required the registrar's office, housing, and residence life, as well as a host of SAS functional areas, to collaborate in order to "give students the knowledge and skill necessary to succeed in first year."

When we compared how units worked together in a cooperative and collaborative fashion at the colleges and at the universities in the sample, the distinction seemed to rest largely in the orientation of the SAS division. The SAS divisions in the colleges cooperated and collaborated largely in an effort to provide the highest-quality service in support of student success. The SAS divisions in the universities appeared to seek collaborative opportunities that provided high-quality service and presented out-of-the-classroom learning opportunities to complement students' in-class learning. In this regard, it seemed that university SAS staff, particularly those with clear programmatic functions, provided service and education in support of student success.

\section{Students as Beneficiaries or Co-constructors}

While students enrol in colleges and universities to ultimately earn diplomas, certificates, and degrees, they can play other roles at their institutions. In one role, students are the beneficiaries of the programs and services delivered and provided by SAS staff. A second role positions students as co-constructors, actively involved in creating their own learning experiences. Though these roles are not mutually exclusive, there was a clear difference between the colleges, which tended to view the students as beneficiaries, and the universities, 
which tended to view students as potential co-constructors. Although there were examples of students creating and shaping their own learning environment within the colleges as peer mentors and orientation leaders, this was less prevalent than at the universities.

SAS staff from the colleges tended to describe students as beneficiaries of programs and services. They discussed the importance of providing excellent customer service to students as their number one priority. One college staff member commented, "Students spread the word about the care they receive," noting that students will "bring you someone else and say, 'Hey, you helped this person. Can you do something to help my friend?" The co-constructive role for students at the colleges tended to be more related to providing feedback on programs and services, particularly around hours of operation. As one staff member noted, "The student government association brings issues to us, for example on [name of building] - we were closing it too often, and it was interrupting some of the study sessions and study space for them, so we had to respond to that, and we do." SAS staff from colleges did not suggest that students should not be co-constructors of the learning environment, only that their divisions tended to view students primarily as program or service beneficiaries, rather than actively involved in developing or providing the SAS division's programs and services.

University SAS staff described a clear desire and, in many cases, an expectation that students would be involved in co-constructing the learning environment. Student co-constructors were typically upper-year undergraduates, who worked under the supervision of SAS staff members to deliver programs or services directly to their fellow students. Examples of students acting as co-constructors were found across SAS divisions: mentoring peers in supported learning group programs, working in residence life, coordinating orientation activities, and leading student associations. One university staff member shared, "There are just incredible programs at the Wellness Centre that reach thousands of students. Students develop these workshops. I mean, they are saving staff so much time and developing skills themselves." Students are teachers as well as learners in their role as co-constructors. As one participant described, "I think we would be crazy not to engage our students in our work. They teach us. There is so much that they know that we do not, especially where technology is concerned." Additional examples included students who serve on advisory committees that approve SAS budgets and provide feedback on new initiatives and programs. University staff members valued and recognized the capacity of students to develop and carry out programs and appeared aware that when students undertook these roles, the division's programs and services were able to reach a broader and larger audience.

A co-constructor approach suggests a partnership between SAS staff and the students. When some ownership or responsibility for learning is invested in students, they become active participants and "feel very much a part of student affairs." Although there were many cases in the universities where students were the beneficiaries of a program or service (and there were many situations where this was entirely appropriate), these SAS divisions have extended the student role and demonstrated a willingness to involve students at a higher level. 


\section{The Challenge of Meeting Increased Access with Increased Service}

Ontario colleges and universities have taken different pathways to increase post-secondary access and enrolment. Colleges, as Crown corporations with clear accountability to the government, have always operated in a more market-oriented model and developed new programs to take advantage of labour market trends. They have expanded their "communities" by broadening the program offerings at their main campuses and simultaneously establishing new programs in communities that either do not have postsecondary institutions or are underserved. Universities, as independent entities created through legislative acts, have taken a more conservative approach and focused mainly on growing their existing undergraduate programs and expanding their graduate offerings. Only a few universities have significant satellite campus structures; many of which are professional programs. By and large, Ontario universities have relied on students coming to them, while the colleges have gone to the students, creating satellite campuses across their catchment areas.

Campus expansion brings with it the very real challenge of providing equitable student services at multiple locations. Though some of the colleges' enrolment growth has been very close to the main campuses, in many cases the growth is occurring at satellite campuses in new cities and smaller, more rural locations. These satellite "campuses" may actually be spaces where only evening classes or programs for very specific and small groups of students are taught. One college's senior officer noted, "It bothers me immensely that I don't have the same standard of service between the campuses. That to me is the biggest single issue that I have-that students ... enjoy the same level of services, [regardless of where they study]." Structurally, providing an equitable level of services across multiple campus locations appeared to be a particular challenge faced by the colleges in the sample.

Increased access also means greater variation in the backgrounds, preparation levels, and previous life experiences of today's post-secondary student. One participant noted, "If you look at the visibility [of student diversity] on this campus, it has profoundly changed in the last five years. People are identifying the type of services necessary for first-generation students, for international students, students with disabilities, etc." Supporting a diverse student body often requires programs and services to be delivered on a one-to-one basis. These include counselling, accessibility, and learning strategies services. Irrespective of the post-secondary sector, SAS staff in these areas reported higher caseloads, packed appointment schedules, and greater demands on their time. One staff member from counselling services said their office was "just trying to keep their heads above water" and that "the people who work in disability services, they are just chock-ablock. They are too busy." Many staff in these areas commented that the only way to cope with the increased demand was to shorten appointments and give less individualized service. Yet, these staff also expressed great concern that the quality of services they were able to give students was decreasing simply due to the volume of appointment requests.

The targeted nature of provincial access funding and sector mandates has led staff at colleges and universities to interact with a more diverse student body. Although there are some constants across the sectors (staff at colleges and universities reported higher numbers of first-generation students, international students, and students who need accommodations), increased access in the colleges leads to greater numbers of mature learners 
and Second Career (a cost-sharing need-based educational grant that provides skills training in high-demand occupations and financial support for laid-off workers in Ontario) students, whereas at the universities, increased access means more graduate students.

The diversity challenge faced by staff in the colleges relates to working with mature or Second Career students. One staff member noted that Second Career students "are older, they have not been in school in 20 years, and there are steps we are taking to help them transition back into school, for those who have not written an exam in 20 years." This staff member went on to note that one of the biggest challenges for these students is basic computer literacy. Providing support for these students while recognizing the computer fluency of the younger generation of students is a challenge for SAS staff at colleges.

With increased provincial funding for graduate study, more universities are expanding their graduate offerings, and a significant shift has been toward supporting graduate student success as well. Unlike undergraduates, who are still more likely to be coming directly from high school, and aged 18 to 22, graduate students do not fit a clear profile. They may be studying at the master's or doctoral level. Their programs of study vary in duration and focus. Some programs are professional and applied, while others are research intensive. University participants noted that in some cases it was unclear whether supporting graduate students was within the SAS division's mandate or that of the school of graduate studies. One participant noted SAS was "starting to get more [graduate students]. I mean we do work with the students to some extent. But we're starting to get more and it's that sort of question about them being legitimate students. They're also part of the community; how can we help them?"

Providing programming and services for this fast-growing set of students of different ages, work experiences, and career expectations is a significant and new challenge for SAS staff at universities. Although the challenges take different shapes due to the differences in access funding and mandate, increasing access and support for a more diverse student body poses real challenges to SAS staff at colleges and universities.

\section{Discussion}

This study identified three key differences between college and university SAS staff members' perceptions of the nature of their work, the role of students, and the challenges of meeting increased access with increased service. First, SAS units within colleges appeared to have a more service-oriented focus, whereas universities tended to have an educational focus as well. Perhaps related to this difference in the orientation of SAS staff (service providers and educators) is that students played a different role in the SAS divisions at colleges than they did at universities. Student affairs and services at the colleges tended to refer to students as beneficiaries of services, while SAS staff at universities engaged students more frequently as co-constructors of the learning environment. Finally, colleges appeared to be more entrepreneurial in manifesting their mandate by establishing a network of satellite campuses to meet increasing post-secondary needs allowing for an expansion of their academic programs. However, we found that increases in SAS program and service provision in these new areas have rarely kept pace with expansion. By contrast, universities, because of their governance structures, have tended to expand less to satellite campuses, focusing largely on graduate expansion. That said, we argue that as universities mimic colleges by growing into new markets, universities' SAS divisions will face many of the challenges the colleges are attempting to address. 


\section{Excellent Service Providers and Educators}

The CACUSS mission statement (1989) emphasizes that "the primary purpose of Student Services is to develop programs and provide services which support and promote student-centered education" (p. 2). The mission statement further holds that "Student Services professionals are educators" (p. 3) and that shaping the learning environment and providing services to individuals and groups are two of the central responsibilities of student services. This historical legacy, within the Canadian context, supports the notion that SAS staff should be both excellent service providers and educators. Yet, we found fewer examples where SAS staff in colleges talked about their work with students from the perspective of educators as opposed to service providers.

Keeling (2008) has urged the field to think beyond the binary choice of being either service providers or educators, but rather to hold the perspective of providing both excellent service and education. The question that then arises is how SAS staff can begin to see themselves as both service providers and educators irrespective of the post-secondary sector in which they work. We assert that part of this orientation shift can be facilitated by senior and mid-level leadership . If the SAS division's senior officer, directors, and managers make an effort to point out the multitude of ways that normal transactional outcomes (like disbursing a student's bursary cheque) also entail an opportunity to educate (on the related topic of financial literacy), SAS staff may begin to see the educational opportunities that their role affords. By reorienting SAS staff to focus on education and service provision, the SAS division is in a better position to be recognized as a full partner in supporting the institution's mission and supporting students to realize their educational and personal goals.

\section{The Benefits of Students as Co-Constructors}

Given the applied nature of college education, compared with universities' research focus, it appears somewhat paradoxical that students at the universities in the sample played a greater role in constructing their learning experience. Recognizing the mandates of Ontario's Colleges of Applied Arts and Technology are to prepare students for the workforce by giving them the training for immediate employment,l our findings suggest there are opportunities for college students to become more involved in leadership, mentoring, and other related SAS roles. When one considers the transferable skills these kinds of opportunities provide to develop human resources and build capacity for students' future employment, it seems natural for colleges to engage more regularly with students in coconstructing their learning environment.

Student engagement literature suggests that the more involved students are in their post-secondary education, the greater the learning opportunity and likelihood of their persistence, educational gains, and graduation (Hu \& Kuh, 2002; Kuh, 2003; Pascarella \& Terenzini, 2005). To the extent that colleges engage their students meaningfully as co-constructors of the learning environment, it stands to reason that these students are more likely to persist, graduate, and find employment in their desired vocation. Colleges in Ontario, unlike universities, have some of their funding tied directly to key performance indicators (KPIs include factors such as graduation rates, employment rates, and loan default rates). With improvement on a college's KPIs serving as a motivating factor, intentionally creat- 
ing engaging opportunities for students to co-construct their learning environment would provide additional opportunities and skill development for college students. Students who can discuss the transferability of the skills they gained would be better positioned for employment upon completing their diplomas. Thus, involving students as co-constructors may improve a college's KPI performance and support student success.

\section{Meeting Increased Access with Increased Service}

In the past 10 years, access to post-secondary education has been a significant priority of the provincial government. In the 2010 Speech from the Throne, the government announced a goal of a 70 percent post-secondary education participation rate. This would be the highest rate of participation in Canada and one of the highest in the world (Higher Education Quality Council of Ontario, 2010). In 2011, the Ontario government pledged to fund 20,000 new spaces for first-entry programs in colleges and universities as well as 15,000 new graduate student spaces (Ontario Ministry of Finance, 2011). These initiatives were in addition to funding that started in 2005, targeted at enroling students in high-demand programs, students from historically underrepresented groups, and highpriority student cohorts including first-generation, Aboriginal, and transfer students in both colleges and universities (Bartleman, 2005). This commitment to access, backed with funding, has been welcomed by Ontario's publicly funded colleges and universities. However, this funding has also required Ontario's SAS staff to think expansively about supporting the success of a highly diverse group of students.

While providing college education in underserved areas appears to be an effective way to increase access, running courses and academic programs in multiple low-enrolment settings presents SAS senior officers with the complex challenge of determining how to provide high-quality, cost-effective services across all of these areas. If the multi-campus approach continues to be the preferred route of colleges (and potentially of the university sector too), senior divisional officers should be involved early in the planning process. This will ensure that SAS needs are considered in concert with enrolment and that service of a similar quality and level is provided across multiple campuses. Much of the success for SAS in working in these multi-campus models will depend on the senior divisional officer's effectiveness in ensuring that formal and informal communication strategies are in place between the various campuses.

With growing enrolment, SAS in universities may actually be able to provide specialized programs and services for various locations. However, to the extent that colleges and universities continue to develop satellite campuses as a means of meeting post-secondary needs, SAS staff will need to become more generalist, as enrolment at satellite campuses will not likely be high enough to justify having many permanent SAS staff on site. Both college and university SAS staff will require additional training to work with an increasing number of students from diverse backgrounds. Curricular, co-curricular, and support systems will need to be intentionally developed to meet the diversity of student needs.

By calling on member states to "provide adequate student services" (p. 9), the communiqué from UNESCO's 2009 World Conference on Higher Education gave momentum and visibility to an international dialogue centred on student services' role in supporting student success. As governments recognize that investment in post-secondary education is critical to developing their economies and societies, understanding how SAS staff per- 
ceive the interaction between their work and organizational structures relative to supporting student success is imperative. As provincial policy makers continue to discuss the merits of increased differentiation and mobility within the post-secondary system, the findings from this study can be used to inform Ontario's dialogue about organizing the programs and services necessary to support students to attain their educational and personal goals. Moreover, as provinces across Canada continue to discuss and further differentiate their post-secondary sectors, findings from the study may contribute to a broader pan-Canadian dialogue.

\section{Acknowledgement}

We would like to acknowledge the Higher Education Quality Council of Ontario for its support of this research.

\section{References}

Ambler, D. A. (2000). Organizational and administrative models. In M. Barr, M. Desler, \& Associates (Eds.), The handbook of student affairs administration (2nd ed.) (pp. 121-133). San Francisco, CA: Jossey-Bass.

American College Personnel Association. (1996). The student learning imperative. Retrieved from http://www.acpa.nche.edu/sli/sli.htm

American Council on Education. (1937). The student personnel point of view. Retrieved from http://www.myacpa.org/pub/documents/1937.pdf

American Council on Education. (1949). The student personnel point of view. Retrieved from http://www.myacpa.org/pub/documents/1949.pdf

Andres, L., \& Finlay, F. (2004). Student affairs: Experiencing higher education. Vancouver, BC: University of British Columbia Press.

Barr, M. (2000). The importance of institutional mission. In M. Barr, M. Desler, \& Associates (Eds.), The handbook of higher education administration (2nd ed.) (pp. 2536). San Francisco, CA: Jossey-Bass.

Bartleman, J. K. (2005, October 12). Strengthening Ontario's economic advantage [speech transcript]. Retrieved from Office of the Premier website: http://www.premier. gov.on.ca/news/event.php?ItemID=5227\&Lang=EN

Brint, S., \& Karabel, J. (1989). The diverted dream: Community colleges and the promise of educational opportunity in America, 1900-1985. New York, NY: Oxford University Press.

Brock University Act. (1964). Statutes of Ontario 1964, c. 127. Retrieved from Brock University website: http://www.brocku.ca/university-secretariat/brock-university-act

Canadian Association of College and University Student Services (CACUSS). (1989). The mission of student services. Position paper available from the CACUSS Secretariat at: contact@cacuss.ca

Composite Learning Index. (2010). Learning to know: Participation in post-secondary education. Retrieved from: http://www.cli-ica.ca/en/about/about-cli/indicators/knowhpse.aspx 
Crookston, B. B. (1994). Student personnel-All hail and fairwell! In A. Rentz (Ed.), Student affairs: A profession's heritage (2nd ed.) (pp. 474-482). Lanham, MD: University Press of America.

Dennison, J., \& Gallagher, P. (1986). Canada's community colleges. Vancouver, BC: University of British Columbia Press, Vancouver.

Dougherty, K. J. (2001). The contradictory college: The conflicting origins, impacts and futures of the community college. Albany, NY: State University of New York Press.

Drewes, T. (2008). Accessibility in Ontario's postsecondary education system: An interprovincial comparative analysis. Toronto, ON: Higher Education Quality Council of Ontario.

Dungy, G. (2003). Organization and functions of student affairs. In S. Komives, D. Woodard, Jr., \& Associates (Eds.), Student services: A handbook for the profession (4th ed.) (pp. 339-357). San Francisco, CA: Jossey-Bass. Sage.

Gibson, W. J., \& Brown, A. (2009). Working with qualitative data. Los Angeles, CA:

Hardy Cox, D., \& Strange, C. (2010). Achieving student success: Effective student services in Canadian higher education. Montreal, QC: McGill-Queen's University Press.

Higher Education Quality Council of Ontario. (2010). Third annual review and research plan. Toronto, ON: Author.

Hirt, J. B. (2006). Where you work matters. Lanham, MD: University Press of America.

Hu, S., \& Kuh, G. (2002). Being (dis)engaged in educationally purposeful activities: The influence of student and institutional characteristics. Research in Higher Education, $43,555-576$.

James, T. (2010). Student services in colleges. In D. Hardy Cox \& C. Strange (Eds.), Achieving student success: Effective student services in Canadian higher education (pp. 195-207). Montreal, QC: McGill-Queen’s University Press.

Jones, G. (Ed.). (1997). Higher education in Canada: Different systems, different perspectives. New York, NY: Garland Publishing.

Jones, G., \& Skolnik, M. (2009). Degrees of opportunity: Broadening student access by increasing institutional differentiation in Ontario. Toronto, ON: Higher Education Quality Council of Ontario.

Keeling, R. P. (2004). Learning reconsidered: A campus-wide focus on the student experience. Washington, DC: American College Personnel Association and National Association of Student Personnel Administrators.

Keeling, R. P. (2006). Learning reconsidered 2: A practical guide to implementing a campus-wide focus on the student experience. Washington, DC: American College Personnel Association, Association of College and University Housing Officers International, Association of College Unions International, National Academic Advising Association, National Association of Campus Activities, National Association of Student Personnel Administrators, and National Intramural-Recreational Sports Association. 
Keeling, R. P. (2008). Educators, service providers, or both? CACUSS Communiqué, $8(2), 15$.

Keeling, R. P., \& Associates. (2011). University of British Columbia portfolio review: Vice President, Students. Final Project Report 1-UBC-201002. New York, NY: Authors.

Kuh, G. D. (2003). What we are learning about student engagement from NSSE. Change, 35(2), 24-32.

Kuh, G. D., Kinzie, J., Schuh, J., Whitt, E., \& Associates. (2005). Student success in college:

Creating conditions that matter. San Francisco, CA: Jossey-Bass.

Kuk, L. (2009). The dynamics of organizational models within student affairs. In G. McClelland \& J. Stringer (Eds.), The handbook of student affairs administration (3rd ed.) (pp. 313-332). San Francisco, CA: Jossey-Bass.

Lincoln, Y. S., \& Guba, E. G. (1985). Naturalistic inquiry. Beverly Hills, CA: Sage.

Lyons, J. (1993). The importance of institutional mission. In M. Barr \& Associates (Eds.), The handbook of student affairs (2nd ed.) (pp. 3-15). San Francisco, CA: Jossey-Bass.

Manning, K., Kinzie, J., \& Schuh, J. (2006). One size does not fit all: Traditional and innovative models of student affairs practice. New York, NY: Routledge.

Mueller, K. (1961). Student personnel work in higher education. Boston, MA: Houghton Mifflin.

Ontario Ministry of Finance. (2011). Ontario budget 2011. Retrieved from http:// www.fin.gov.on.ca/en/budget/ontariobudgets/2011/

Ouellette, M. (2010). Student services in university. In D. Hardy Cox \& C. Strange (Eds.), Achieving student success: Effective student services in Canadian higher education (pp. 208-220). Montreal, QC: McGill-Queen's University Press.

Pascarella, E. T., \& Terenzini, P. T. (2005). How college affects students (Vol. 2): A third decade of research. San Francisco, CA: Jossey-Bass.

Rossman, G. B., \& Rallis, S.F. (2003). Learning in the field: An introduction to qualitative research (2nd ed). Thousand Oaks, CA: Sage.

Seifert, T., Arnold, C. H., Burrow, J., \& Brown, A. (2011). Supporting student success: The role of student services within Ontario's postsecondary institutions. Toronto, ON: Higher Education Quality Council of Ontario.

Skolnik, M. L. (2005). The Rae review and the structure of postsecondary education in Ontario. In C. M. Beach (Ed.), A challenge for higher education in Ontario (pp. 7-25). Kingston, ON: John Deutsch Institute, Queen's University, and McGill-Queen's University Press.

Skolnik, M. L. (2010). A look back at the decision on the transfer function at the founding of Ontario's Colleges of Applied Arts and Technology. Canadian Journal of Higher Education, 4O(2), 1-17.

Strauss, A., \& Corbin, J. (1998). Basics of qualitative research techniques and procedures for developing grounded theory (2nd ed.). London, UK: Sage. 
Sullivan, B. (2010). Organizing, leading, and managing student services. In D. Hardy Cox \& C. Strange (Eds.), Achieving student success: Effective student services in Canadian higher education (pp. 165-191). Montreal, QC: McGill-Queen's University Press.

UNESCO (United Nations Educational, Scientific and Cultural Organization). (2009, July 8). 2009 world conference on higher education: The new dynamics of higher education and research for societal change and development [communiqué]. Retrieved from http:// www.unesco.org/fileadmin/MULTIMEDIA/HQ/ED/ED/pdf/WCHE_2009/FINAL\%2O COMMUNIQUE\%20WCHE\%202009.pdf

Weingarten, H. P., \& Deller, F. (2010). The benefits of greater differentiation of Ontario's university sector: Final report. Toronto, ON: Higher Education Quality Council of Ontario.

\section{Contact Information}

Tracia A. Seifert

Ontario Institute for Studies in Education

University of Toronto

tricia.seifert@utoronto.ca

Tricia A. Seifert is an assistant professor in the higher education program at the Ontario Institute for Studies in Education. She is interested in the organization and administration of student affairs and services and how post-secondary institutions organize to support student success. She teaches graduate courses on quantitative research methods and student services in post-secondary institutions.

Jeff Burrow is a doctoral student in the higher education program at the Ontario Institute for Studies in Education. His professional experience and research interests include study abroad, student affairs outside of Canada and assessment and evaluation in student affairs. 